\title{
LUMINESCENCE IN POLYNOID WORMS
}

\author{
By J. A. C. Nicol \\ The Plymouth Laboratory
}

(Plates I and II and Text-figs. I-24)

Luminescence is well known in polychaete worms and occurs sporadically in unrelated species having different modes of life. Families containing luminescent species are Aphroditidae, Tomopteridae, Syllidae, Alciopidae, Chaetopteridae, Cirratulidae and Terebellidae. Among Aphroditidae luminescent forms are confined to subfamily Polynoinae, ${ }^{1}$ and the response is limited to the dorsal scales which are a diagnostic feature of these animals. Bonhomme (1942) has recently demonstrated in polynoid worms that light production is intracellular. This contrasts with certain other polychaetes such as Chaetopterus, in which luminescence is extracellular and is due to the discharge of a luminescent secretion. The regulation of luminescence in Chaetopterus has recently been investigated in some detail (Hasama, I94I; Nicol, I952b); and I considered that a study of the physiology of intracellular luminescence in polynoids would form an interesting comparison with that work (see Harvey, I940, I952, for general reviews of animal luminescence).

\section{Distribution of Luminescence in the Subfamily Polynoinae}

Luminescence has been reported in the following polynoids, the nomenclature based on Fauvel (1923). Six of these species are illustrated in Text-fig. I.

Luminescent species

Harmothoë impar (Johnston)

H. impar (=Evarne impar)

$H$. longisetis (Grube)

H. imbricata (L.)

H. imbricata (=Polynoe cirrata)

$H$. spinifera Ehlers (=Polynoë torquata)

$H$. spinifera $(=H$. torquata $)$

$H$. lunulata (Delle Chiaje)

H. lunulata (= Polynoë lunulata $)$

H. aspera (Hansen) (= Polynoë aspera)

Lagisca extenuata (Grube)

Gattyana -cirrosa (Pallas)

Lepidasthenia stylolepis Willey

Eunoë nodosa Sars (sp. ?)

Polynoë scolopendrina Savigny

Malmgrenia castanea McIntosh

Acholpë astericola (Delle Chiaje)

Lepidonotus squamatus (L.) (= Polynoë squamatus)

1 McIntosh (1900) and Hartman (1938a,b) treat this subgroup as a separate family.
Authority

Fauvel, 1923; Bonhomme, 1942

McIntosh, I900; Bonhomme, I942

Fauvel, I923

McIntosh, I872, 1900

Kallenbach, I883

Jourdan, I885

Darboux, 1899

McIntosh, I877, I900; Fauvel, I923

Bonhomme, I942

Khvorostànsky, I892

Darboux, 1899

McIntosh, I900

Lloyd, I907

McIntosh, 1872

McIntosh, 1872, I900

Original

Darboux, I899; McIntosh, I900;

Kutschera, I909; Dahlgren, I916;

Fauvel, I923; Bonhomme, I942

Dahlgren, I9I6 
This list is certainly not final. It is also important to record species of polynoids that do not luminesce, in order to restrict the field of further search and investigation. Contrary to Dahlgren (see preceding list), the two species of Lepidonotus, L. clava (Montagu) and L. squamatus (L.) are not luminescent. This is noted by Jourdan (I885) and Bonhomme (I942) and I can confirm the observations of these two authors. Halosydna gelatinosa M. Sars and Lepidasthenia argus Hodgson are two other non-luminescent species.
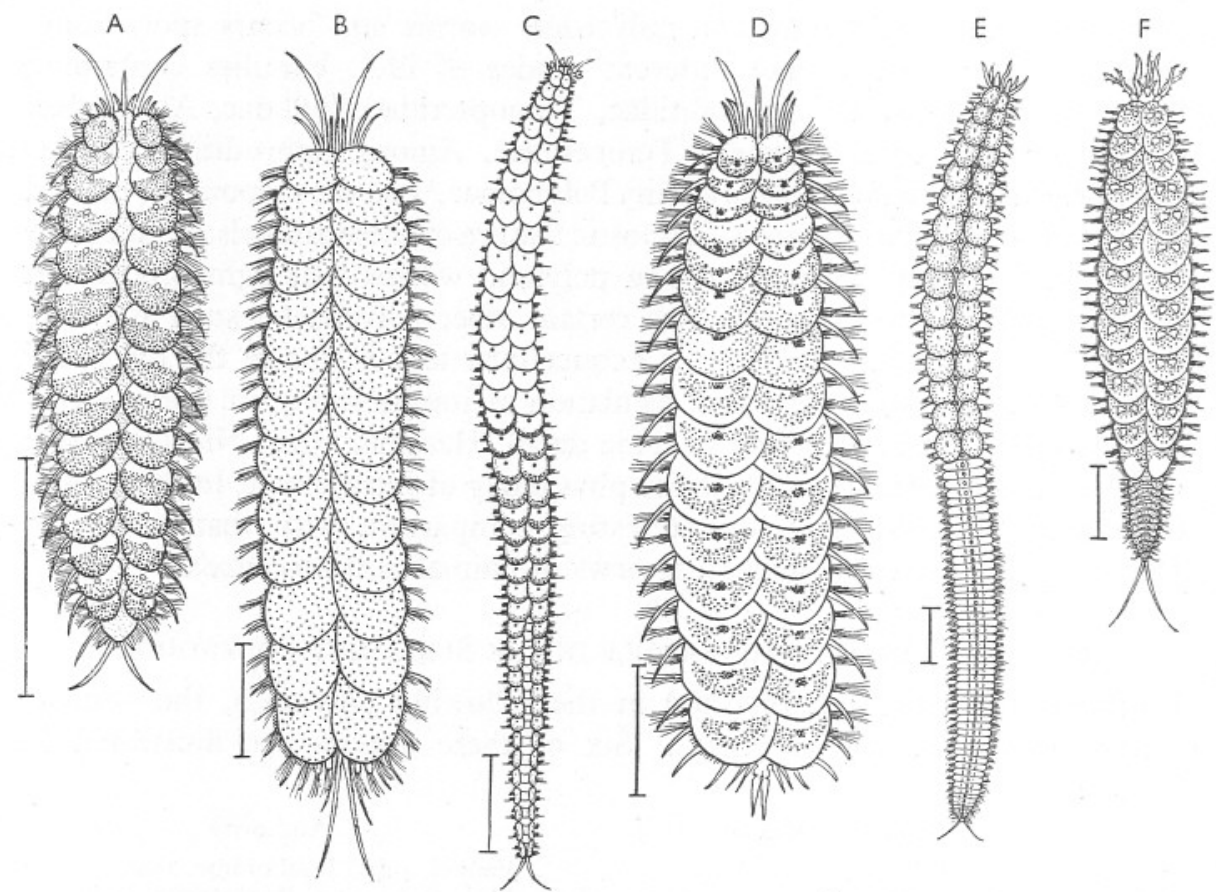

Text-fig. I. Luminescent species of polynoids, drawn from life. A, Malmgrenia castanea; B, Gattyana cirrosa; C, Acholoë astericola; D, Harmothoë lunulata; E, Polynoë scolopendrina; F, Lagisca extenuata. Scale $5 \mathrm{~mm}$.

A number of authors have merely recorded luminescent genera, viz. Polynö̈, Harmothoë and Lepidonotus. With repeated changes in nomenclature these observations are only of general value.

\section{Histology and InNeRvation of the Luminescent Tissue}

There is general agreement that luminescence in polynoids is confined to the scales which cover all or part of the dorsal surface, according to the species. These structures are disk-shaped, and are attached to the body above the parapodium by a relatively thin stalk or elytrophore. Fauvel (I923) notes 
that the elytra are inserted on segments $2,4,5,7,9, \ldots, 23,26$, and subsequently on each successive third segment; segments without elytra have an elongated dorsal cirrus.

\section{GENERAL STRUCTURE OF THE ELYTRUM}

An elytrum is a thin disk covered externally by a cuticular layer which may be smooth or adorned on its superior surface with rugosities and papillae. Underneath the cuticle is a unicellular epidermis (or hypodermis) which is continuous except over the insertion of the stalk. Frequently the scale bears a pigment pattern which is due to the aggregation of dark granules in the epidermal cells.

Extending vertically between the upper and lower surfaces of the scale is a strut-work of rather fine fibres of somewhat indeterminate nature. They are patently extracellular structures, presumably of connective tissue nature; their staining affinities are poor, but they are coloured by eosin. Since they are not concerned with luminescence it was unnecessary to analyse them further in this investigation. The meshwork of spaces among the fibres communicates with the general body cavity through the stalk. Well-developed muscles are present in the elytrophore, some of them inserted on the rim forming the junction between stalk and elytrum, but none extend into the body of the elytrum (Pls. I and II) (Darboux, I889; Haswell, I882; Jourdan, I885; Pflugfelder, I933).

In the light-producing species there is a layer of luminescent cells or photocytes on the lower surface of the scale. These cells are actually modified epidermal cells. Bonhomme (I942) has described in Harmothoë lunulata how the density of pigment is reduced in the epidermal cells of the upper surface over the region occupied by photogenic tissue. This restriction of pigment pattern is a general feature of luminescent species, and presumably is an adaptation which allows maximal emission through the upper surface of the scale (Text-fig. 2).

\section{Innervation of the Elytrum}

An easily recognizable nerve trunk ascends in the wall of the elytrophore, and on reaching the elytrum forms a well-demarcated nodal point from which nerves radiate out in all directions towards the periphery of the scale. These nerves divide, subdivide, and become attenuated towards their termination (Pl. I, fig. I). Kallenbach (1883) refers to the node of nervous tissue above the elytrophoral stalk as a ganglion, but gives no details of the occurrence of nerve cells.

The nervous supply of the elytrum has been described and figured by Haswell (I882), Jourdan (I885), and Bonhomme (I942), to which I can add few additional observations. In favourable material (e.g. Acholoë, Malmgrenia), the nerves in the scales can be seen in the living state, but staining is necessary 
to bring out the finer nerves and fibres. Many of the smaller fibres terminate in relation to the papillae on the dorsal surface, or go to sensory terminals on the exposed margin of the scale. The dorsal papillae are generally believed to represent the loci of sensory structures. In the figures of Jourdan (1885, I887), Bonhomme (I942) and others, the papillae are drawn with a central canal through which runs a fibre that is connected with an underlying group of ganglionic cells (Darboux, I899; Haswell, I882; Panceri, 1874).
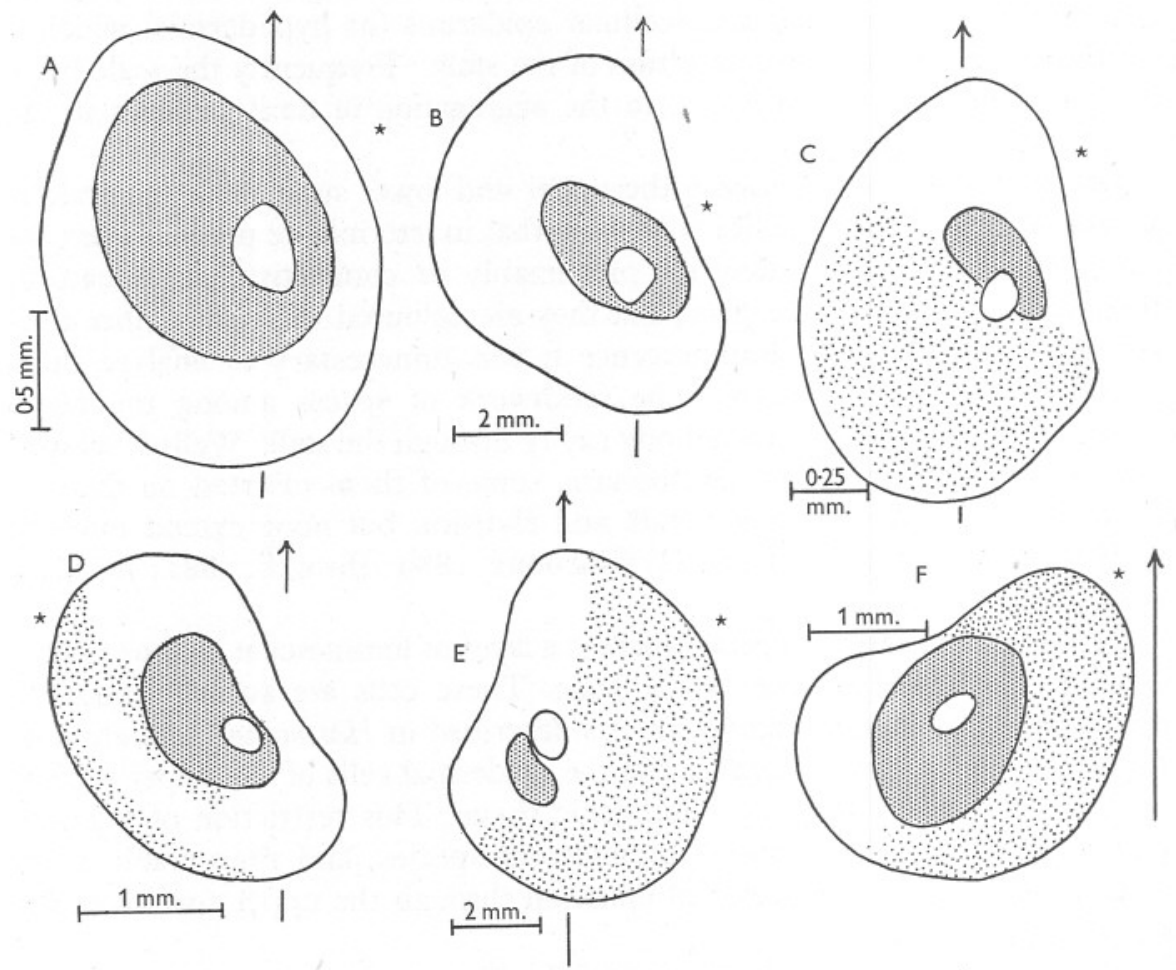

Text-fig. 2. Outline drawings of the scales of polynoids to show the extent of the luminescent area. A, Acholoë; B, Gattyana; C, Malmgrenia; D, Harmothoë; E, Lagisca; F, Polynoë. Magnification as shown. The central clear area is the region of attachment of the elytrophore. The luminescent area is marked with mechanical shading. Pigmented areas are dotted. Direction cephalad is indicated by the arrow, and the external margin by an asterisk.

By means of silver impregnation (Bielschowsky method). Bonhomme has shown up the elytral nerves of Harmothoë lunulata (=Polynoë lunulata). Besides the sensory fibres and peripheral sensory cells he has discovered numerous efferent fibres which leave the main nerve trunks, and pass downwards to reach the photogenic cells, or even to penetrate into them and run between the secretory granules. 
I can confirm these descriptions from preparations of Acholoë astericola treated with various nerve-stains. The scales of this species can be stained readily with supravital methylene blue, whereas other species (Lagisca extenuata, Polynö̈ scolopendrina) proved refractory. Clear pictures were obtained of nerves radiating outwards from a nodal point at the edge of the stalk, and ramifying over the expanse of the scale (Pl. I, fig. I). This is the broad picture of the nervous supply. Silver-impregnation with Bodian's activated protargol has been tried with varied success on the scales of several species (Polynö̈, Acholoë and Lagisca). In sections so treated the nerve trunk can be traced through the wall of the elytrophore into the centre of the elytrum. Here it gives rise to a well-marked ganglion consisting of a central mass of nerve fibres about which are grouped several distinct nerve cells (Pl. II, figs. 7, 8). From this central ganglion nerve trunks proceed peripherally through the centre of the scale (Pl. II, fig. 9). In their course the nerves give off fine nerve fibres which run obliquely or vertically downwards. In fixed material they are very fine, less than I $\mu$ in diameter. Fairly certainly, therefore, all the photogenic cells are innervated by fine nerve fibres, and these emerge from the nerve trunks which radiate outwards from the elytrophore like the spokes of a wheel. Consequently, the nerve fibres which occur in the elytrum are of two types, viz. sensory fibres, and efferent fibres supplying the luminescent cells.

\section{Photogenic Tissue}

The disposition and structure of the photogenic cells have been debated for some time, and the solution of this problem is necessary to understand the physiological processes involved in light production in polynoids. Kutschera (I909), followed by Dahlgren (I9I6), believed that the luminescent cells were grouped under the dorsal papillae of the elytra. Although unable to detect an extracellular secretion they supported the view that a photogenic material was discharged to the exterior through a canal in the papilla. These papillae, are however, probably receptor structures. The true photogenic cells form a glandular layer in the lower surface of the scale of luminescent species (Harvey, I952).

The photogenic tissue in Harmothoë spinifera (= Polynoë torquata) has been described by Jourdan (1885). He showed that it occupied the region of the scale around the elytrophore and consisted of a layer of mucus-cells which replaced the epidermis over part of the lower surface of the scale. In his figure (3) masses of large granules are shown in the photogenic epithelial cells. Recently, the photogenic cells of $H$. lunulata have been described in more detail by Bonhomme (1942), who has made confirmatory observations on H. impar and Acholoë astericola. These cells are tall, polygonal in crosssection, and contain a large oval nucleus. Proximally the cells are filled with large oval or round granules which are closely packed together; distally, the 
granules decrease in size. Immediately under the cuticle the cell shows a basal cytoplasmic layer free of secretory granules and containing mitochondria. On histochemical grounds the granules were considered to be protein in nature, and were regarded as representing the luminescent material. The non-luminescent species of Lepidonotus lack a layer of corresponding photogenic tissue in their elytra.

I have prepared sections of the elytra of six luminescent species, namely Acholoë astericola, Malmgrenia castanea, Harmothoë lunulata, Gattyana cirrosa, Polynö̈ scolopendrina and Lagisca extenuata, and one non-luminous species, Lepidasthenia argus, and I can confirm Bonhomme's observations. The

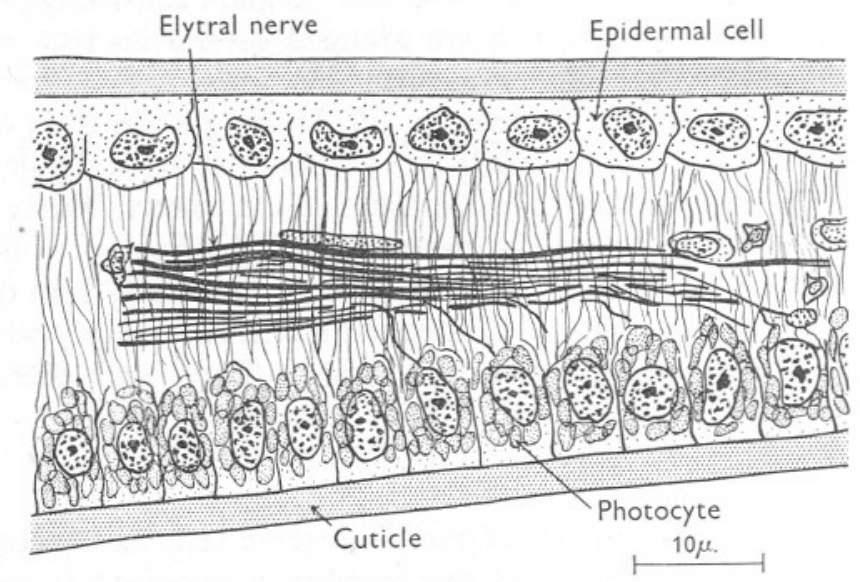

Text-fig. 3. Drawing of a vertical section through the elytrum of Acholoë astericola, showing photocytes, elytral nerves and connective tissue framework.

photogenic cells in the first six species listed above form a layer of unicellular epithelium on the lower surface of the scale near the elytrophore region, and extending a greater or lesser distance peripherally, according to the species (Pls. I and II). In all species the photogenic cells are packed with coarse granules, which are acidophilic after fixation in Bouin's and Helly's fluids, and stain well with eosin and orange $G$, and also with azocarmine (Textfig. 3). Some measurements are as follows:

\begin{tabular}{lcc}
\multicolumn{1}{c}{ Species } & Dimensions of cell & Size of granules \\
Lagisca extenuata & $(\mu)$ & $(\mu)$ \\
Polynoë scolopendrina & $3-4 \times 8-14$ & $2 \cdot 5-3$ \\
Acholoë astericola & $5-6 \times 8-25$ & $2-5$ \\
Malmgrenia castanea & $3-4 \times 8-18$ & $2-5$ \\
Gattyana cirrosa & $6-8 \times 8$ & 2 \\
Harmothoë lumulata & IO-18 $8 \times 4-8$ & $2-7$ \\
& $6-18 \times 4-5$ & $3-5$
\end{tabular}

There are considerable specific differences in the area of the scale occupied by the photogenic tissue. This is brought out in Text-fig. 2, compiled from 
Bonhomme and from original observations. Drawings (Text-fig. 2) illustrate the region of the scale which luminesces in different species. Reconstructions have also been made from serial sections of whole elytra of Acholoë to show the area of scale occupied by photogenic tissue, and reasonably close correspondence was found to exist between the area occupied by photogenic cells and the luminescent region.

It follows that luminescence is intracellular in polynoid worms, and takes place in a layer of eosinophilic photogenic cells lying on the lower surface of the elytrum. Presumably the granules occurring in these cells are the luminescent material.

\section{Miscellaneous Observations on Luminescence in Polynoids}

Early observations on luminescence in polynoids, reviewed by Darboux (I899), do little more than record its occurrence.

Luminescence is evoked by mechanical stimulation of the animal. Acholoë astericola, the species which has been most investigated, is very sensitive to mechanical disturbance; and, if the container is shaken or the animal touched, a few or many scales will luminesce, depending on the strength of the stimulus. Falger (1908) notes that when an animal is touched, the luminescent response proceeds anteriorly and posteriorly over the elytra from the stimulated region (Dahlgren, I9I6; Darboux, I899). When an animal is quickly cut into two, however, only the elytra of the posterior portion lighten, while the anterior half of the animal remains dark (Harvey, I940, I952; Kutschera, I909). This kind of response is apparently common to all luminescent species, and has been observed in Lagisca extenuata and Malmgrenia castanea, as well as in Acholoe astericola. In Polynoë scolopendrina the posterior half of the body is devoid of scales, and when this region is transected there is no luminescent response. When, however, the anterior half of the body is cut across, the scales posterior to the cut become luminescent.

These observations show that luminescence in polynoids is under nervous control, since the excitation proceeds along the length of the body from the stimulated region. With suitable tactile stimulation the luminescent response proceeds both forwards and backwards along the worm. Consequently, pathways exist for the transmission of excitation anteriorly and posteriorly through the nerve cord. Since a sharp cut produces luminescence in the posterior region only, these nervous pathways are apparently functionally polarized, as has been observed in Chaetopterus (Nicol, I952a, b). Possibly, strong stimulation is required to overcome the resistance in anteriorly directed nervous pathways, in which resistance stands at a higher level than in pathways leading posteriorly.

A notable feature of luminescence in polynoids is that the light appears in flashes or scintillations when the animal is irritated. This has been recorded 
for various species including Harmothö imbricata and H. lunulata (Haswell, I882; McIntosh, I877, I900). In Acholoë astericola, according to Falger (I908) and Kutschera (I909), the response lasts a few seconds and elytra light up intermittently for 20 or 30 times in quick succession.

The luminescent polynoids readily autotomize their elytra when irritated, and these separated scales continue to glow for some time when cast off from the animal. The nerve trunk is severed when a scale is cast off, and the excitation produced is sufficient, presumably, to start the scale flashing. Bonhomme observes that in the intact animal there are reflex pathways involving sensory receptors on the scale, the nerve cord, and efferent nerve fibres, all of which are concerned with mediating the luminescent response, but in the isolated scale only efferent fibres are in a position to be excited so as to lead to a response (Haswell, I882; Jourdan, I885; Kallenbach, I883; McIntosh, I900).

There are reports that the intact animal and isolated scales recover the ability to luminesce after stimulation when they are left for some time in sea water. Falger's results (1908) seem to indicate that recovery is a rather slow process.

Electrical stimulation has been employed by several workers (Bonhomme, I942; Kutschera, I909; Panceri, I874). Falger (1908), using $A$. astericola found that direct current at make stimulated the animal to luminesce. By alternating the current he produced momentary flashes corresponding to each change of current, and finally, with faradic stimulation, he obtained prolonged responses in which the light appeared to flicker rapidly. These results are interesting in appearing to show that the response to a single shock is a quick flash. This kind of response should lend itself well to physiological analysis, and such a study was undertaken.

\section{Results Obtained with Photoelectric Recording Material and Methods}

Recordings were made of luminescence in several species of polynoids which were collected in the Plymouth area: Lagisca extenuata (Grube), a common species on the shore, in dredgings, and among Chaetopterus tubes; Harmothoë lunulata (Delle Chiaje), commensal with Arenicola marina L., Echinocardium cordatum (Pennant), and Leptosynapta inhaerens (O. F. Müller); Polynö̈ scolopendrina Savigny, a commensal with Polymnia nebulosa (Montagu) which is most easily collected from among Chaetopterus tubes; Acholoë astericola (Delle Chiaje), a commensal living in the ambulacral groove of Astropecten irregularis (Pennant); Gattyana cirrosa (Pallas), occurring in the burrows of

Amphitrite johnstoni Malmgren; and Malmgrenia castanea McIntosh, a commensal species found about the mouth region of Spatangus purpureus O. F. Müller (Text-fig. I). The physiological basis of luminescence appears to be 
identical in all these species, and the results are considered together. Acholoë astericola and Polynoë scolopendrina were used in most of the investigations, but sufficient records were obtained of luminescence in the other species to show that their behaviour was the same.

Each scale is an effector unit, and individual scales may be expected to show independent time courses of excitation and response. Therefore, to obtain quantitative data and to analyse the luminescent response, records must be secured from single scales. As brought out in the preceding section, the scales flash when detached from the body, and their luminescent ability thereby becomes reduced. To prevent this, and to obtain scales in a functionally fresh condition for examination, the animals were anaesthetized with an isotonic solution of magnesium chloride for $30 \mathrm{~min}$. before handling them. With Acholoë astericola, which is very sensitive to tactile stimulation, and which luminesces strongly when an attempt is made to evict it from its host, it is best to anaesthetize starfish and worm together. This treatment narcotizes and immobilizes the worm, and the scales can be removed with fine scissors under a dissecting microscope without causing them to luminesce. Subsequently the magnesium should be washed out with several changes of sea water for an hour or more. Detached scales in sea water can be stored for a few days in a refrigerator $\left(4-8^{\circ} \mathrm{C}\right.$.), until required for experimentation.

To record luminescence from a single scale, the scale was mounted on a pair of platinum electrodes lying in a moist chamber which was placed underneath a multiplier photocell. The arrangement is shown in Text-fig. 4 . The light from the scale was focused on the photocathode of the photocell. The latter was connected through a direct coupled amplifier to a doublebeam oscilloscope. Since there is much variation in the intensity of light produced by different species, it is necessary to regulate the degree of amplification, and this was achieved both by control of the amplifier, and by adjusting the voltage on the photocell by means of a potentiometer.

Electrical stimulation consisted of shocks of brief duration (capacitor discharges) delivered from an electronic stimulator which permitted independent control of frequency, voltage, and pulse duration.

\section{Observations}

\section{Effect of Single Shocks (Acholoë)}

When an elytrum is stimulated with a single shock it gives a bright luminescent response. This frequently takes the form of a series of flashes. An example of such a response is given in Text-fig. 5. The frequency of flashing is rapid at first, often at rates of 5 or more per sec. The pattern of flashing frequently takes the following form. After a rapid initial outburst lasting about a second, the rate of flashing settles down to a steady level of about I per sec. which continues for around I min., and then gradually 
begins to decline while the flashes themselves decrease in intensity. Textfig. Io shows a plot of flashing interval against time, taken from one of the photographic records, and bringing out certain of the features just described. In some records the rate of flashing increases instead of decreasing as the flashes die away, but this kind of response is less frequent.

A second characteristic of this repeated flashing or flickering is seen in a falling off of intensity. Initially the intensity of the flashes is relatively high, but thereafter the height of the separate responses decreases with time. This

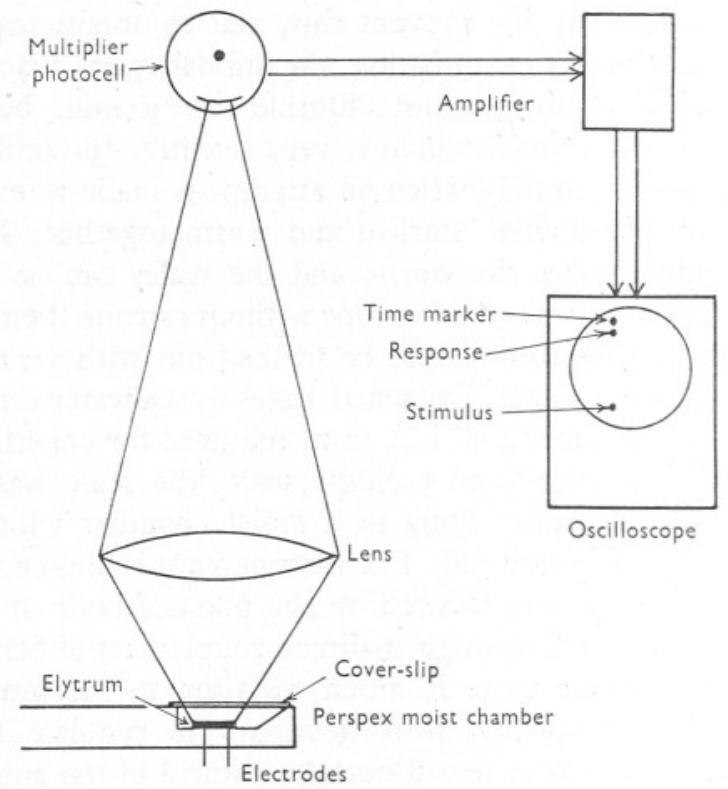

Text-fig. 4. Diagram of the apparatus used in recording the luminescent flashes of single elytra from polynoids. Not drawn to scale.

is shown in Text-figs. 5 and 6 . When the rate of flashing is fairly rapid (intervals of less than $0.6 \mathrm{sec}$.), the light intensity does not return to zero between flashes (Text-fig. 5).

During repetitive flashing (induced by a single stimulus) the level of intensity reached by the first few flashes is often noticed to rise rapidly to a maximum, and then gradually decrease (Text-fig. 5). This effect shows in Text-fig. 8, which gives a plot of the light intensity of individual flashes against time. In the record from this elytrum the increase in intensity follows a linear course for the first three flashes, and then slowly decreases. Maximal intensity of flashes is reached in one-third of a second (third flash), and intensity of subsequent flashes falls to one-half the value of the maximal flash in II sec. (I5 flashes). The rate of decay of intensity of subsequent 


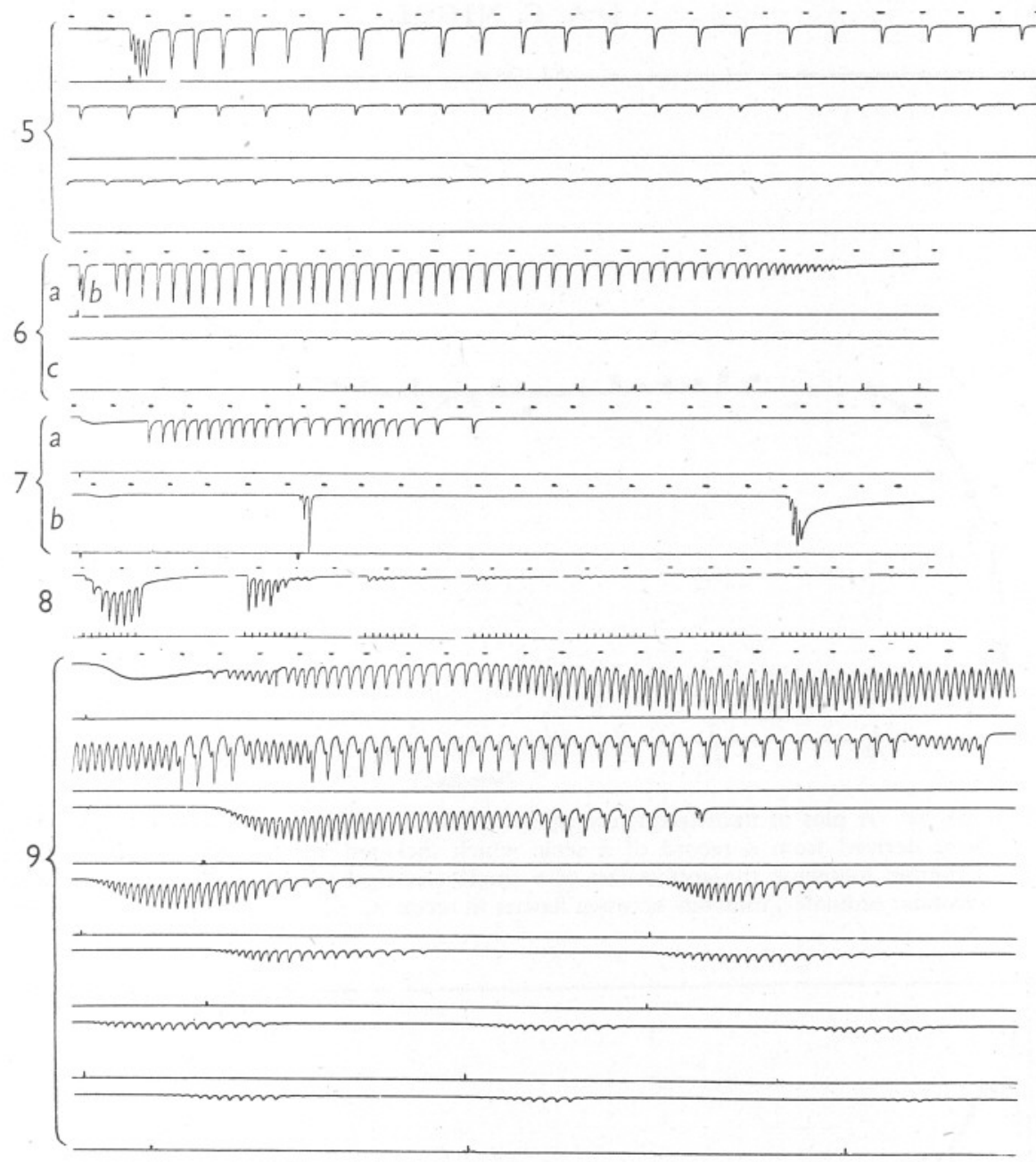

Text-fig. 5. Prolonged flashing from an elytrum of Acholoë, as the result of a single electrical stimulus. This is a continuous record. Time scale above, pips at I per sec. Deflexions downwards of the oscilloscope upper beam are records of the luminescent responses. Stimulus appears as pip on the lower line (oscillograph lower beam).

Text-fig. 6. Rhythmic flashes in an elytrum of Acholoë following the application of a single stimulus $(a, b)$, and repeated stimuli $(c)$. Stimulation frequency, 42 per min. in $c$. Time scale, I per sec. I sec. elapsed between records $a$ and $b$; I sec. between $b$ and $c$.

Text-fig. 7. Luminescent responses of the elytra of Lagisca: $a$, flickering induced by a single impulse; $b$, effect of two stimuli separated by an interval of $6 \mathrm{sec}$. Time scale I per sec. The small prolonged deflexion immediately following each stimulus may be due to some direct depolarization of the luminescent cells.

Text-fig. 8. Fatigue of the luminescent response of Acholoë as the result of successive bursts of electrical stimuli. These consisted of 7-8 shocks at a frequency of 6 per sec. Time scale I per sec.

Text-fig. 9. Rhythmic flashing of an elytrum of Gattyana. This is a continuous record showing consecutive periods of rhythmic flashing, each period of flashing being induced by a single shock. Time scale I per sec. 


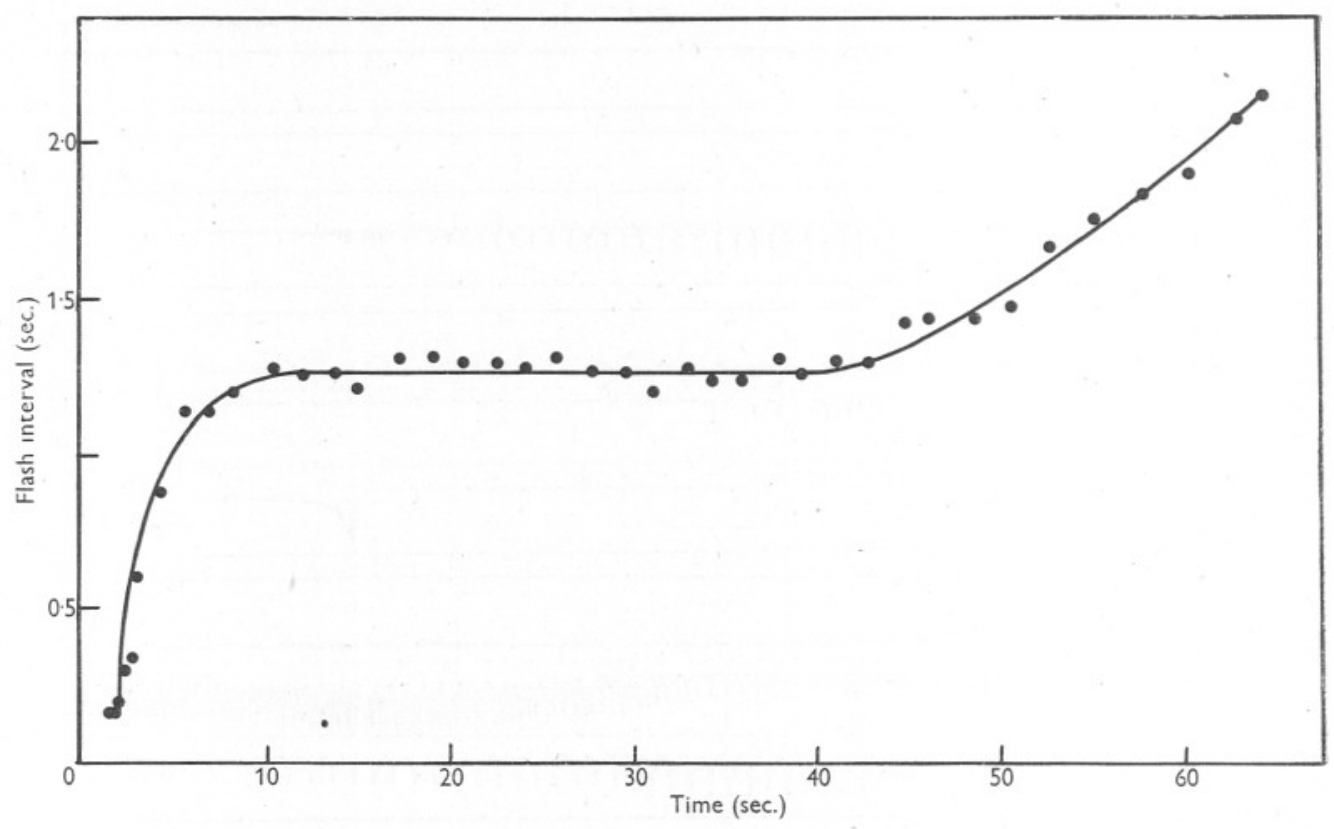

Text-fig. Io. A plot of flash-frequency against time for an elytrum of Acholoë. The data were derived from a record of a scale which flickered rhythmically for more than a minute following the application of a single electrical stimulus. Abscissae, time in seconds; ordinates, intervals between flashes in seconds.

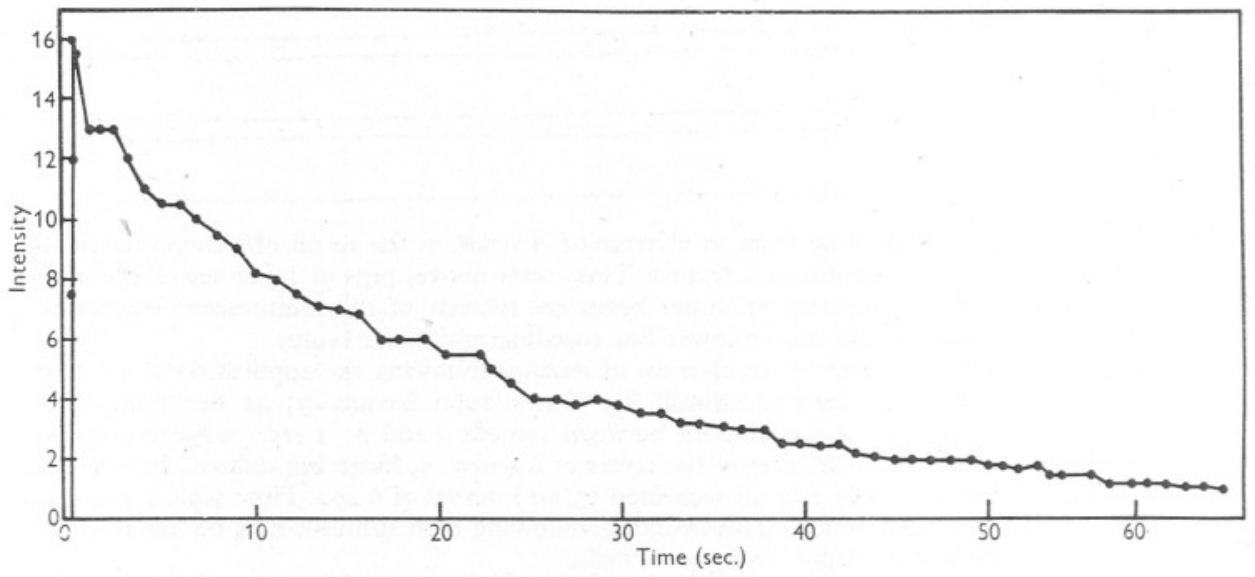

Text-fig. II. A plot of the light intensity of successive flashes in an elytrum of Acholoë against time. Rhythmic flashing was induced in the preparation from which this record was obtained by a single electrical shock. Light intensity in arbitrary units. Time in seconds. Each point on the curve represents the intensity of a separate flash. 
flashes follows an exponential curve, and in about I min. is 10\% of the maximal flash, and is barely measurable (Text-fig. II). A curious feature of some records is that the flashes sometimes occur in bursts with considerable pauses in between. This is recorded in Text-fig. 6 (Acholoë) and in Textfig. 7 (Lagisca). After a pause of as much as IO-I4 sec. the scale may spontaneously start to flash once more, and continue until its powers of luminescence are exhausted.

\section{Fatigue}

Several factors are involved in determining the magnitude of the response, and one of the most important is the onset of fatigue. After a scale has been flashing for some time the flashes gradually become weaker. A highly excitable scale may continue flashing until it is nearly or completely exhausted, when the light becomes very weak or disappears. Subsequent stimulation then fails to evoke a response. Other scales, less excitable, respond with shorter periods of flashing to single shocks or brief bursts. These scales can be fatigued by repeating the stimulation at suitable intervals, when the consecutive flashes or groups of flashes gradually decrease in amplitude (Text-figs. 8 and 9). Isolated scales which have been stimulated to exhaustion show little or no recovery of luminescent ability when left overnight in sea water.

Since the luminescent response is an intracellular process, some oxidation of a cellular constituent must occur. Bonhomme (1942) has shown that after excitation there is no apparent decrease in the amount of intracellular secretory material in the photocytes when the luminescent response has run its course. Harvey (1926, I952), moreover, has observed that fresh elytra of Acholoë are non-fluorescent, but once they are stimulated and luminescence has subsided, they display marked yellowish fluorescence. It appears, therefore, that some waste or end-product of the luminescent reaction is strongly fluorescent, and by this means a transformation of the intracellular constituents concerned with luminescence can be detected.

There are suggestions by earlier workers (p. 72) that polynoids recover the ability to luminesce after a period of rest, but since no comparative measurements were made these statements are rather indefinite. My observations show that recovery is a very slow process in isolated elytra. Apparently, then, either the luminescent reaction is irreversible, or reduction of the oxidized photogenic material takes place very slowly within the photocytes. Repeated flashing, therefore, progressively exhausts the store of potentially luminescent material until the scale becomes dark, and renewal of this store is dependent upon protracted chemical transformations within the photocytes. Isolated scales, of course, are deprived of trophic supplies from the animal, and this lack may restrict the energy sources available for reconstitution of the photogenic material. 
It is of interest to compare fatigue of luminescence in different forms. In glowworms and fireflies (Lampyridae), luminescence is also an intracellular phenomenon, but these animals are able to produce light for many hours and do not show fatigue. On the other hand, various marine Crustacea which possess photophores, e.g. Nyctiphanes, Sergestes, fatigue readily as the result of repeated stimulation (Terao, I9I7; Vallentin \& Cunningham, I888). I have myself shown (Nicol, I952a), that the luminous polychaete Chaetopterus variopedatus discharges a luminescent secretion into the surrounding sea water, and when it is repeatedly excited the amount of secretion, and consequently light, rapidly diminishes with each period of stimulation. These few selected observations demonstrate that there exists extensive variation in the ability of different animals to maintain sustained or recurrent luminescence at a high level. This is of first importance in considering the role of luminescence in the life of the animal, and in seeking to unravel the physiological events involved in the control of light-production in each species.

Most biochemical work on luminescent substances has been done on the photogenic secretion of Cypridina (see Harvey, 1952, for a review of the relevant literature). Cypridina luciferin has been prepared in a highly purified state and this substance is known to undergo an irreversible oxidation when it is converted into oxyluciferin, with the release of light energy, through the activity of luciferase. These exact and detailed studies afford some ground for believing that in Chaetopterus, and possibly in polynoids, we are also dealing with an irreversible oxidation of photogenic material.

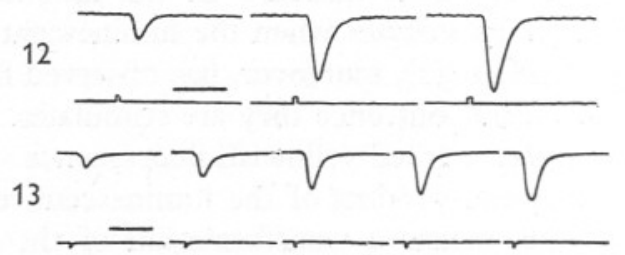

Text-fig. I2. Single flashes in an elytrum of Acholoë, induced by single impulses. Stimulating shock shown on lower line. There was an interval of $3 \mathrm{sec}$. between the first and second stimuli, and $5 \frac{1}{2} \mathrm{sec}$. between the second and third. Time scale, shown by the horizontal line at the bottom left, Ioo msec.

Text-fig. I3. Luminescent responses of Polynoë scolopendrina. This record shows consecutive single flashes, I per stimulus, induced by a slow rate of stimulation (I per sec.). Time scale below, roo msec. Note the progressive increase in the height of consecutive flashes.

\section{Time Characteristics of Single Flashes}

Favourable records of single flashes photographed at fast camera speeds permit an analysis of the temporal relations of the luminescent response (Text-fig. I2). In Acholoë the luminescent response (flash) begins I8-20 msec. after the stimulus, rises to a peak in $18-23 \mathrm{msec}$. from initial deflexion, and returns to base-line (zero intensity) from maximal deflexion in $45^{-80} \mathrm{msec}$. 
Mean values are $19 \mathrm{msec}$. for latent period and $83 \mathrm{msec}$. for total flash duration. Time for half decay from peak intensity ranges from II to I9 $\mathrm{msec}$. The response times for Polynö scales are somewhat similar. The latent period varies from I3 to $21 \mathrm{msec}$., peak intensity is reached $26-30 \mathrm{msec}$. after initial deflexion, and the response is finished $108 \mathrm{msec}$. after maximal intensity is reached. Half decay from maximal deflexion occurs in about $17 \mathrm{msec}$. (Text-fig. I3).

\section{Comparison of the Luminescent Responses of Different Species}

The luminescent responses of different species of polynoids appear to conform to the same pattern as that found in Acholoë. In Lagisca extenuata (Text-fig. I4), Harmothoë lunulata (Text-fig. I5), Malmgrenia castanea (Textfig. I6), Polynoë scolopendrina (Text-fig. I7), and Gattyana cirrosa (Textfig. 9), a single shock either evokes one flash or initiates flickering, according to the condition of the elytrum. Rates of rhythmic flashing in the various

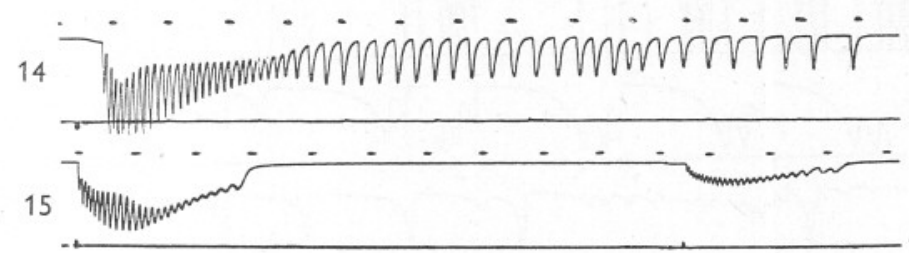

Text-fig. I4. Luminescent responses of an elytrum of Lagisca, showing rhythmic flashing induced by a single electrical stimulus. Time scale, I per sec.

Text-fig. I5. Rhythmic flashing in a scale of Harmothoë lunulata as the result of a single electrical stimulus. Time scale, I per sec.

species show the following ranges: Lagisca, 9-2 per sec.; Polynö̈, 9-4 per sec.; Harmothö̈, 9-I per sec.; Malmgrenia, 8-I per sec.; Gattyana, 9-2 per sec. Rates of flashing in Acholoë, for which a large series of records are available, vary from I8 to I per sec., but usually lie below ro per sec. In general, it may be said that the scales of all species examined begin flashing at a rate of about 9 per sec., and the rate progressively falls off to a frequency of about I flash per sec. Other features common to all species are the gradual build-up in intensity of the first few flashes, and, once maximal flash intensity is reached, the progressive diminution in intensity of successive flashes as fatigue sets in.

\section{Effect of Stimulating the Nerve Cord}

Most experiments have been made, for convenience, on isolated scales. To get additional information about the nature of nervous control of the luminescent response, some additional experiments were tried on G. cirrosa in which the nerve cord was stimulated. The preparations consisted of pieces of the body amounting to three or four segments. A single scale was left on 
each piece, and the body-wall was slit longitudinally along the ventral surface on one side of the nerve cord opposite to that bearing the scale. The preparation was then mounted on a glass plate, with the elytrum downwards, above the photocell. A micromanipulator was used to place a pair of needle electrodes on the nerve cord in that segment bearing the scale. Conveniently, the entire central nervous system, brain and nerve cord, in all polynoids is

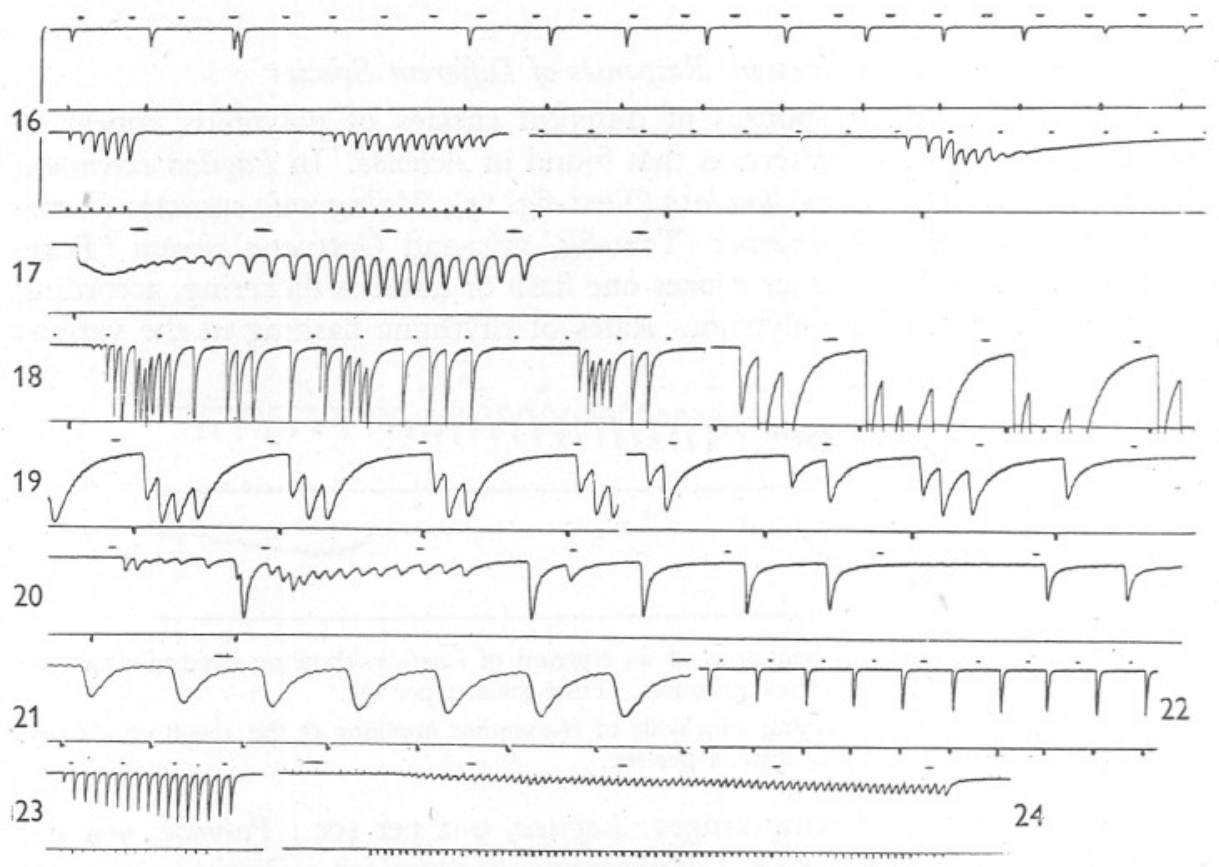

Text-fig. I6. Single flashes and repeated flashes from an elytrum of Malmgrenia as the result of electrical stimulation. Time scale, I per sec.

Text-fig. I7. Luminescent responses from a scale of Polynoë. Rhythmic flashing induced by a single stimulus. Time scale, I per sec.

Text-figs. I8-24. Luminescent responses from an elytrum of Gattyana cirrosa resulting from stimulation of the ventral nerve cord. Time scale in all records, I per sec. Fig. I8: rhythmic flashing induced by a single electrical shock. Fig. 19: rhythmic flashing in response to stimulation at a frequency of 72 per min. Fig. 20 : rhythmic flashing induced by a pair of stimuli. Fig. $2 \mathrm{I}$ : burst of shocks at a frequency of about 5 per sec. The response takes the form of a single flash for each stimulus. Fast paper. Figs. 22 and 23 : responses to bursts of stimuli at $\mathrm{I}$ and $5 \mathrm{per}$ sec. respectively. Note the gradual increase in intensity of successive responses. Fig. 24: burst of stimuli at 20 per sec. The rate of flashing follows that of stimulation.

easily recognizable in being coloured bright scarlet and visible through the body-wall. The colour is presumably due to haemoglobin, as in Aphrodite (see Fordham, I925). Shocks of minimal strength (threshold) were used in order to restrict the stimulation to the nerve cord. The strength of shocks 
required to stimulate the nerve cord was found empirically to be only a small fraction of that necessary to stimulate an isolated scale. Consequently, the possibility of a spread of the stimulus to the scale itself can be excluded in these experiments.

As in isolated scales, a single shock applied to the nerve cord usually evokes a series of rhythmic flashes (Text-fig. I8). A gradual increase in the intensity of the first few consecutive flashes appears in some of these records (Text-figs. I8 and I9), and some preparations showed considerable irregularity in the pattern of responses, both in height and timing (Text-fig. I8 and 20). The irregularity which appears in some of the Gattyana records suggests strongly that several neuro-effector units are present, each one consisting of a group of photocytes supplied by one neurone, and that these units may be responding at slightly different rates, and be out of phase.

Stimulation at higher frequencies is shown in Text-figs. 2I and 24. Above I per sec. the flashes often follow the stimuli faithfully, and successive flashes increase gradually in intensity.

The conclusion from these observations is that the luminescent responses of the elytrum are controlled by the nervous system; and that efferent pathways exist from the nerve cord to the photocytes in the elytrum. It is significant also that a single impulse from the nerve cord will cause repetitive flashing in the elytrum, possibly through the intermediation of the ganglion situated in the latter structure.

\section{Discussion}

The most striking feature of the luminescent response of polynoids is that it usually takes the form of quite rhythmic flashes. The evidence presented shows that the response is under nervous control and is normally evoked by tactile stimulation (touch or mechanical disturbance). A single electrical shock, mechanical injury to an isolated scale, and autotomy of the scale result in rhythmic flashing. Without further information there is little value in speculating on the mechanism responsible for this effect, but suggestions that would be worth further exploration are injury potentials from severed nerve fibres, rhythmic oscillations in the soma of ganglion cells supplying the photocytes, and reverberation of impulses in some system of closed neuronal arcs in the elytrum. Since electrical stimulation of the nerve cord as well as of the isolated elytrum causes rhythmic flashing, it appears that this type of response is characteristic of the normal animal, and a mechanism involving the elytral ganglion may be operating.

A second point of interest, revealed by the photographic records, is the gradual increase in intensity of the first few discrete consecutive flashes in a rhythmic response, or under repetitive stimulation. There is good evidence here for a process of facilitation taking place at the neuro-effector junctions, 
and closely analogous in many respects to the corresponding phenomenon described in neuro-muscular physiology. The quick flashes, closely following nervous stimulation, and the sharp records which can be obtained are very suitable for physiological analysis, and further studies are being pursued.

The regular rhythmic flashing, often lasting for a minute or more, and leading to exhaustion of the luminescent material, may in itself have marked functional significance. A mechanism of this kind allows discontinuous light emission over a much longer period of time than would be effected by continuous emission at the same intensity, and is a more economical method of utilizing a given amount of photogenic material. It can be argued that rhythmic flashes at rates of Io to I per sec. are adequate to attract and secure the attention of another animal, and thereby fulfil their intention. A flickering light also may be more effective as a photic stimulus than a continuous light; but here experimental confirmation is required.

Several authors have commented on the possible significance of luminescence in polynoids, and have suggested that it acts in the nature of a sacrifice lure (Dahlgren, I916; Haswell, I882; Kutschera, I909). This viewpoint is based on the behaviour of the animal. As noted previously, only the posterior half of the animal luminesces after transection. The anterior half is capable of directed locomotory movements, whereas the posterior half shows writhing movements but retains its same relative position. It has therefore been argued that when a polynoid is attacked and part of it is seized, the luminescing posterior region holds the attention of the predator, while the anterior region has the opportunity of escaping. Dahlgren (I9I6) presents an illustration by Horsfall which depicts such a situation. The anterior region of a polynoid is, of course, capable of regenerating the missing segments. Active, luminescent polynoids also possess a well-developed muscular mechanism for autotomizing their scales and these are readily cast off when the animal is irritated. Such isolated scales have been observed to flash rhythmically when removed from the body, and could well serve the function of a sacrifice lure. The reaction time is also fairly rapid, the first flash occurring in about $\frac{1}{50}$ th of a second after stimulation of the nerves, and this would make the mechanism quite efficient. Since the scale soon exhausts itself after a series of flashes, the mechanism is evidently designed to function only at infrequent intervals. Such a theory, of course, must remain speculative until direct evidence is adduced to substantiate it.

It is of some interest to speculate on the evolution of luminescence among polynoids. In the family Aphroditidae, luminescence is confined to the subfamily Polynoinae, and to certain genera of the latter only. Known luminescent genera are Harmothoë, Lagisca, Polynö, Acholoë, Eunoë and Malmgrenia. Except for the species Lepidasthenia stylolepis, Lepidasthenia and Lepidonotus are non-luminescent. Discussing the affinities of the Polynoinae, Darboux (I899) groups together the first four genera as closely related and probably 
derived from some common form, such as Harmothoë. Evidence suggests that they may'have evolved independently of a second group including Lepidasthenia and Lepidonotus. Except for Lepidasthenia stylolepis, luminescence would seem to have appeared in some ancestral form common to one group of polynoids, and has been retained by its modern derivatives. This is a simpler explanation than one which assumes that luminescence has evolved on a number of separate occasions in this subfamily. Luminescence may, of course, have been lost by certain species, for example, L. argus.

\section{SUMMARY}

Six species of luminescent polynoids of the Plymouth fauna have been studied, namely Lagisca extenuata, Gattyana cirrosa, Harmothö̈ lunulata, Polynö̈ scolopendrina, Acholoë astericola and Malmgrenia castanea. Their scales are luminescent, and the light is produced by granular eosinophilic photocytes, which form a unicellular layer on the lower surface of the scale. The nervous supply of the elytrum is described, and the luminescent response is shown to be under nervous control. Luminescent responses from all six species have been recorded by the use of a photomultiplier cell and oscilloscope. The normal response has been found to consist of a series of rhythmic flashes, from 9 to I per sec., lasting up to I min. Some characteristics of the luminescent responses are given, and the part they may play in the normal life of the animal is discussed.

\section{REFERENCES}

Bonномme, C., 1942. Recherches sur l'histologie de l'appareil lumineux des Polynoïnés. Bull. Inst. Océanogr., No. 823.

DAHLGREN, U., I9I6. The production of light by animals: Fourn. Franklin Inst., Vol. I8I, pp. 243-6I.

Darboux, J. G., I899. Recherches sur les Aphroditiens. Trav. Inst. Zool. Univ. Montpellier et Stat. Mar. Cette. Mem. No. 6.

FALGER, F., I908. Untersuchungen über das Leuchten von Acholoe astericola. Biol. Centrbl., Bd. 23, pp. 64I-49.

Fauvel, P., I923. Polychètes errantes. Faune de France, 5, 488 pp., Paris.

Fordham, M. G. C., 1925. Aphrodite aculeata. L.M.B.C. Mem. xxvir, London: Hodder and Stoughton.

Hartman, O., I938a. The types of the polychaete worms of the families Polynoidae and Polyodontidae in the United States National Museum and the description of a new genus. Proc. U.S. Nat. Mus., Vol. 86, pp. 107-34.

- 1938b. Annotated list of the types of polychaetous annelids in the Museum of Comparative Zoology. Bull. Mus. Comp. Zoöl. Harvard, Vol. 85, 31 pp.

HaRvey, E. N., I926. On the inhibition of animal luminescence by light. Biol. Bull., Vol. 5I, pp. 85-8.

— 1940. Living Light. Princeton, N.J.: University Press.

- 1952. Bioluminescence. New York: Academic Press.

HASAMA, B., I94I. Úber die Bioluminescence bei Chaetopterus variopedatus Renier im bioelektrischen sowie histologischen Bild. Zeit. wiss. Zool., Bd. I54, pp. 357-72. 
HASWELL, W. A., I882. On the structure and functions of the elytra of the aphroditacean annelids. Ann. Mag. Nat. Hist., Vol. Io (Series 5), pp. 238-42.

Jourdan, E., I885. Structure des élytres de quelques Polynoës. Zool. Anz., Bd. 8, pp. $128-34$.

- I887. Structure histologique des téguments et des appendices sensitifs de l'Hermione hystrix et du Polynoe grubiana. Arch. Zool. Exp. Gén., T. 5 (2 Série). pp. 9I-I22.

KallenbaCH, E., I883. Ueber Polynoë cirrata O.Fr.Mllr. Inaug. Dissert. University Jena, $34 \mathrm{pp}$.

KhvorostÀnSKY, C., I892. Sur la lumination des animaux de la mer Blanche. Inter. Congr. Zool. Moscow, Vol. 2, pp. 185-6.

KutscherA, F., I909. Die Leuchtorgane von Acholoe astericola Clprd. Zeit. wiss. Zool., Bd. 92, pp. 75-102.

LLOYD, R. E., I907. Notes on phosphorescence in marine animals. Rec. Ind. Mus., Vol. I, pp. 257-6i.

McIntosh, W. C., I872. On the abyssal theory of light, the Protozoic-absorption theory, and the Azoic-mud theory, propounded in the reports of H.M.S. Porcupine, I869 and I870. Ann. Mag. Nat. Hist., Vol. 9 (series 4), pp. I-I3.

—_ I877. On British Annelida. Trans. Zool. Soc., Vol. 9, pp. 371-94.

I900. A monograph of the British annelids. Vol. I, Part 2, 444 pp., London: Ray Soc.

Nicol, J. A. C., I952a. Studies on Chaetopterus variopedatus (Renier). II. Nervous control of light production. Fourn. Mar. Biol. Assoc., Vol. 30, pp. 433-52.

- 1952b. Studies on Chaetopterus variopedatus (Renier). III. Factors affecting the light response. Fourn. Mar. Biol. Assoc., Vol. 3I, pp. II3-44.

PANCeri, P., I874. Intorno alla luce che emana dai nervi delle elitre della Polynoe. R.C. Accad. Napoli, Vol. I3, pp. I43-47.

Pflugfelder, O., I933. Zur Histologie der Elytren der Aphroditiden. Zeit. wiss. Zool., Bd. I43, pp. 497-537.

Terao, A., I917. Notes on the photophores of Sergestes prehensilis Bate. Annot. Zool. Fap., Vol. 9, pp. 299-3I6.

Vallentin, R. \& Cunningham, J. T., I888. The photospheria of Nyctiphanes Norvegica, G.O. Sars. Quart. Fourn. Micr. Sci., Vol. 28, pp. 319-4I.

\section{EXPLANATION OF PLATES I AND II}

\section{Plate I}

Fig. I. Scale of Acholoë stained supravitally with methylene blue (scale, $0.5 \mathrm{~mm}$.).

Figs. 2-6. Horizontal sections through elytra to show internal structure. Fig. 2: Harmothoë $(25 \mu)$. Fig. 3: Gattyana (1о $\mu)$. Fig. 4: Polynoë $(25 \mu)$. Fig. 5: Acholoë $(20 \mu)$. Fig. 6: Lagisca $(5 \circ \mu)$. Heidenhain-azan and haematoxylin-eosin.

\section{Plate II}

Fig. 7. Section through elytrophore and scale of Malmgrenia (Heidenhain-azan). Scale, I00 $\mu$.

Fig. 8. Section through the central region of the elytrum of Acholoë, to show elytral ganglion and origin of an elytral nerve. (Bodian silver stain). Scale, $20 \mu$.

Fig. 9. Section through an elytrum of Acholoë to show elytral nerve and photogenic cells. (Bodian silvar stain.) Scale, $20 \mu$. 


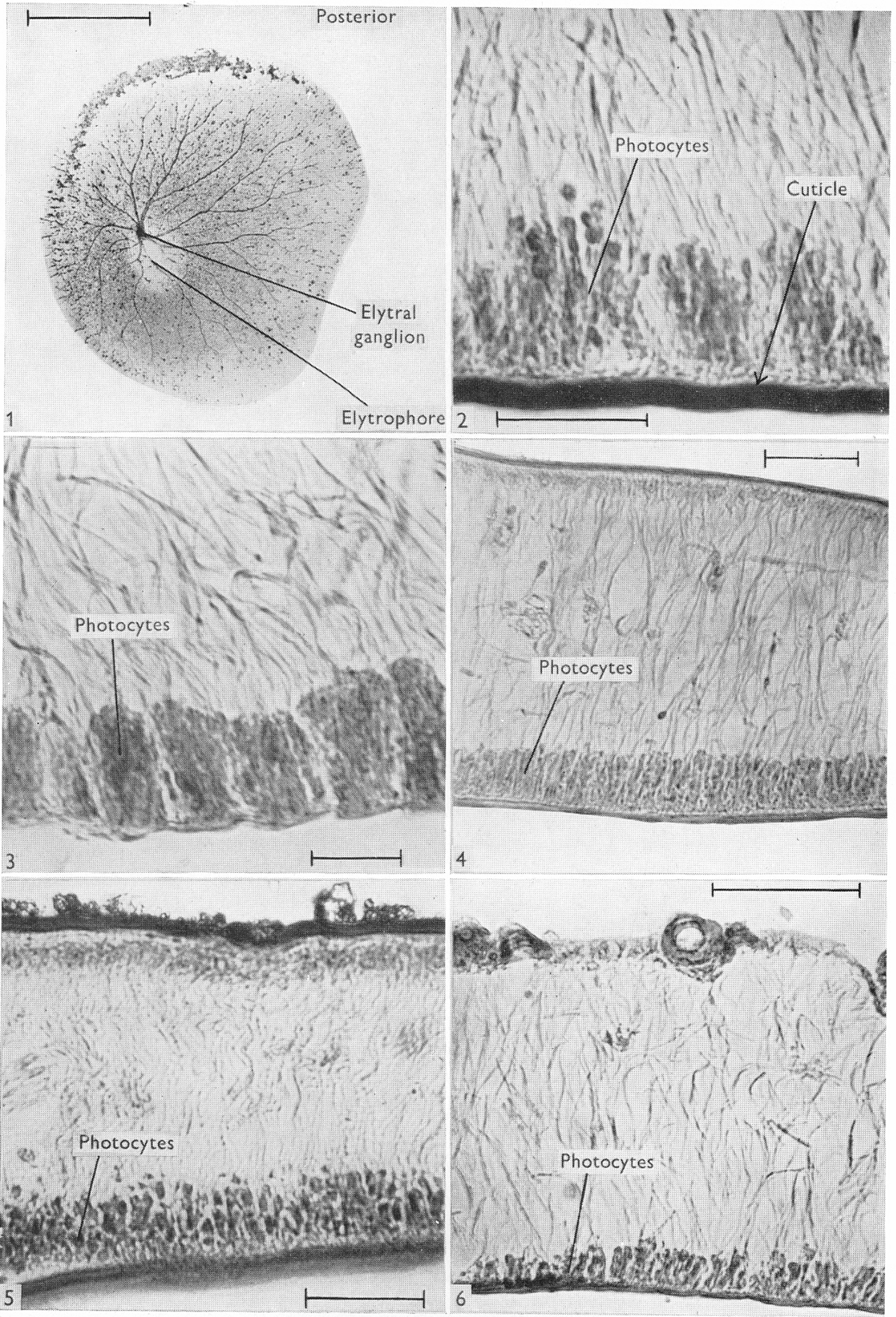

Figs. I-6. 


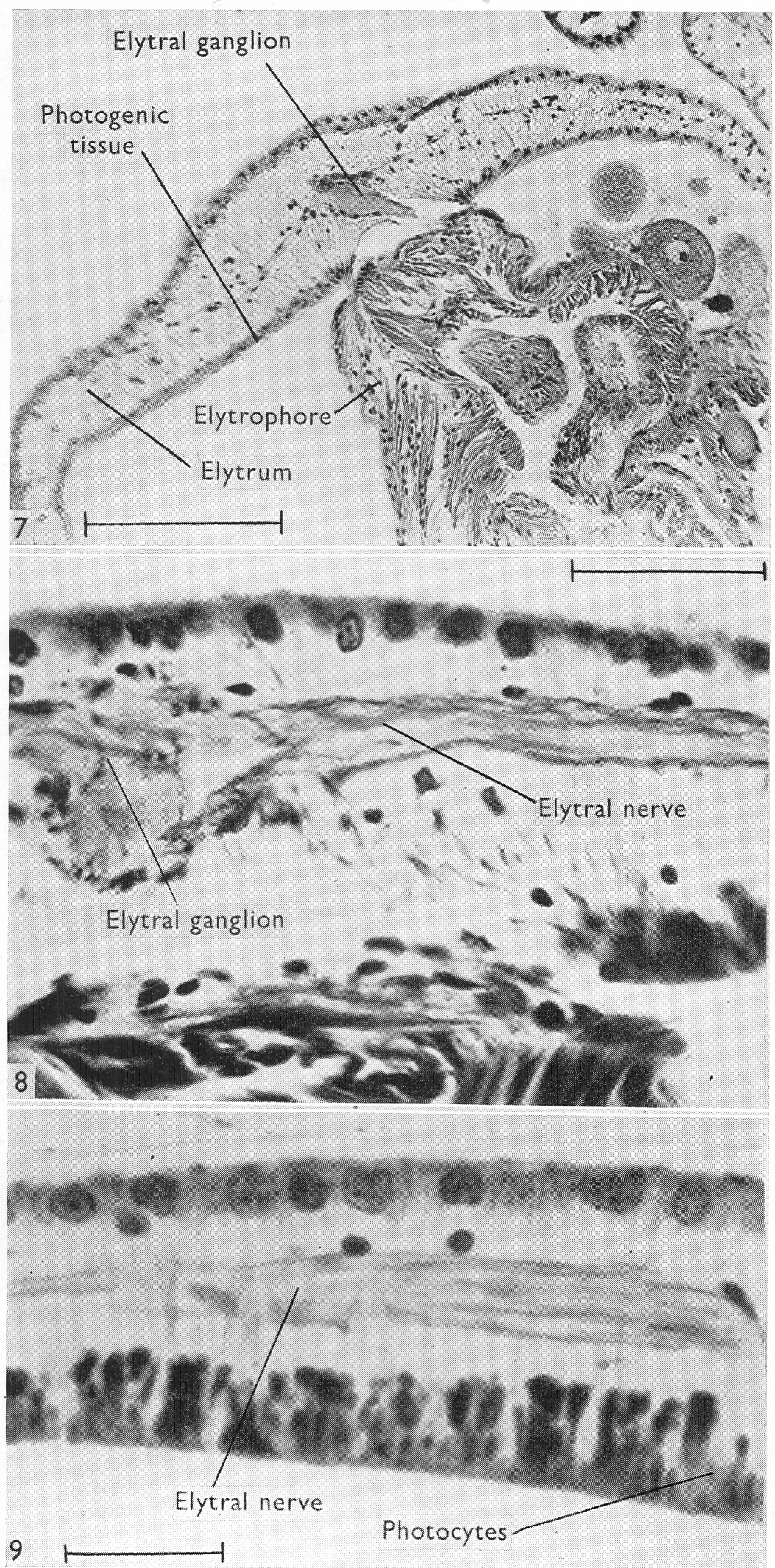

Figs. 7-9. 